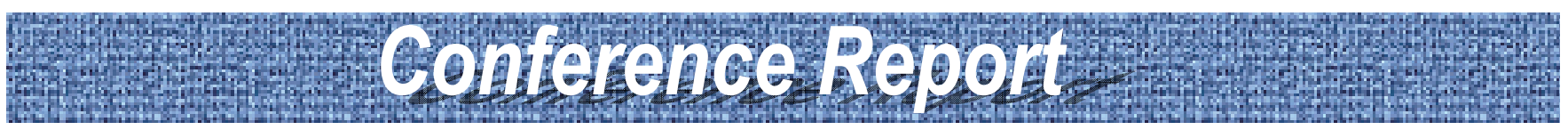

\title{
IEEE Energy Conversion Congress and Exposition (ECCE2010) September 12 - 16, 2010, Atlanta, USA
}

\section{会議の概要}

2010 年 9 月 12 日から 16 日までの 5 日間，米国ジョー ジア州アトランタ市 Hilton Atlanta Hotel において ECCE2010 (IEEE Energy Conversion Congress and Exposition) が開催された。アトランタ市は，コカ・コーラ，デルタ航 空，CNN など日本でも有名な企業が本社を置くアメリカ合 衆国南部の商業・経済の中心地である。大会期間中は晴天 が続き，日中は最高気温が $30^{\circ} \mathrm{C}$ 近くまで上がったが湿度が 低いためからだるような暑さは感じられなかった。ECCE は, PESC (IEEE Power Electronics Specialists Conference)と IAS (IEEE Industry Applications Society) $の$ Industrial Power conversion Systems 領域 (Electric Machines Committee, Industrial Drives Committee, Industrial Power Converter Committee, Power Electronic Devices and Components Committee）に関する技術プログラムが合同で開催された新 しい国際会議であり，今回は第二回目の開催となる。その 論文発表件数も非常に多く，投稿された 1262 件の論文の中 から 666 件が採択され（採択率 $53 \%$ ），そのうち 539 件が Oral Session, 126 件が Poster Session において発表された。

\section{会議の印象}

12 日(学会初日)に 8 件のチュートリアルが, 14 日の朝に プレナリー講演が 2 件行われた。チュートリアル,プレな りー講演のどちらにおいても PVやWind Energy System 等の 再生可能エネルギーに関する講演が行われておりエネルギ 一問題に対して高い関心がある事を感じた。技術セッショ ン（Oral Session）に目を向けてみると去年開催された ECCE2009 では見られなかった plug-inHEV/EV への給電設 備や非接触による給電方式に関して新たに 2 セッションが 追加されるなど plug-inHEV/EV を普及段階一移行するため の技術についての発表が多く行われていた。給電設備に関 しては各国の規格が統一されていない段階でもあり海外の 研究者が行っている給電技術に関する発表は非常に興味深 かった。Poster Sessionについては全 126 件が 2 回のセッ ションに分けられ活発な議論がなされていた。筆者が研究 内容の説明を受けたポスターの付近では，ほとんどの発表 者が複数の聴講者を相手に質疑応答をしており盛況な印象 を受けた。また今回筆者は発表者として学会に参加した。 発表日の朝 7 時から Author's Breakfast が行われ，各セッシ ヨンの発表者および座長が同じテーブルに着席し朝食を取 りながら発表時の注意事項等の説明を聞く。国際学会では 各発表の始まりに座長から発表者の紹介をして頂くのが通 例だが今回は Author's Breakfast 中に紙を渡されその場で自 己紹介文を書いた。朝食中は座長が発表者全員に気を配っ
てくれ，筆者には「緊張しているようだが大丈夫か」と声 をかけてくれた。緊張というよりは会話の半分が聞き取れ ず困っていたのだが，なんとか知っている英語でコミュニ ケーションをとる事ができ有意義な時間であった。違った 環境で研究をされている方々とじっくり話しをする絶好の 機会でもあるので，次回までにはもう少し自分の思いもう まく伝えられるように英会話を勉強したいと強く感じた時 間であった。講演時間は質疑を含めて 25 分が与えられるた め質疑応答にも十分な時間を取ることができると感じた。 三日目の夜にはバンケットが行われた。学会参加者のご家 族も参加する事ができる非常ににぎやかな会食である。バ ンケットでは毎回趣向を凝らしたショーが開催され参加者 を楽しませてくれる。今回は非常にきれいなゴスペルの歌 声と学会コミッティによる生演奏が行われた。図 1 は学会 コミッティによる生演奏の様子である。ECCE2010の General Chair をされている Tom Habetler 氏自らがギターを 手にして演奏をされ会場を盛り上げていた。

次回 ECCE は，米国アリゾナ州フェニックスで 2011 年 9 月 17 から 22 日の日程で開催される。Digest の締め切りは, 2011 年 1 月 15 日である。

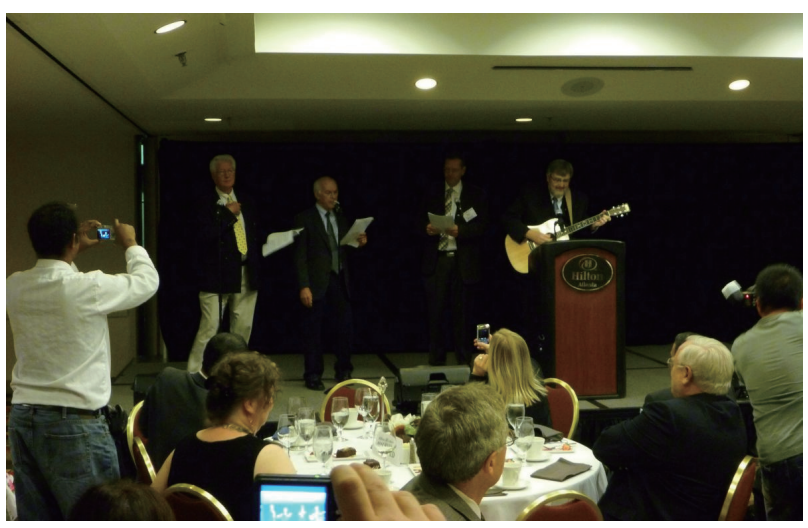

図 1. バンケットの様子

\section{最後に}

海外学会において毎回楽しみにし ている事の一つに現地の食事があ る。今回は日本の大学の先生方とご 一緒させて頂き「SUSHI」を食べに 行った。右の図は「SUMO ROLL」

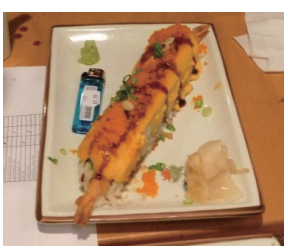
である。海老が丸ごと酢飯と甘いツースにこれでもかと言うくらい 包まれた逸品であった。次回はどんな食べ物に出会えるか今か ら楽しみである。

橋野 哲（本田技術研究所）

(平成 22 年 9 月 30 日受付) 